\title{
Analysis of the Value and Advantages of Financial Literacy and Digitalization to the Individual
}

\author{
Afzal Sayed Munna ${ }^{*}$-0000-0001-7302-8037, Rehana Khanam ${ }^{2}$ \\ 1University of Wales Trinity Saint David, London \\ 2RTH United Kingdom Educare Limited \\ *e-mail: *a.munna@uwtsd.ac.uk ${ }^{1}$, info@rthedu.com ${ }^{2}$
}

\section{Article Information}

Received: November 11, 2020

Accepted: November 27, 2020

Online: June 01, 2021

\section{Keywords}

Teaching and financial learning capability, digitalization society, e-financial literacy

\begin{abstract}
Digital literacy is the ability to analyze, evaluate, and create a teaching and learning media which enables adults and youth to understand complex communication. Fintech has transformed the history of the financial sectors and places an individual at significant advantages. Therefore, this research study has examined how digital knowledge could provide an opportunity to learn financial capability. For this research, the authors have selected Bankers, Teachers, Information Technology (IT) professionals, and university students from Bangladesh and United Kingdom to respond to our questions. In this research study, the authors aim to determine the participant's financial literacy level and digital knowledge about individual adults' advantages. The authors have developed hypotheses, financial literacy tests, survey questionnaires. The survey was carried out by financial professionals and university students in the UK and Bangladesh. A small group of participants was selected on a later stage using convenience sampling to conduct a smallscale interview. The research findings have found that present financial decision-making and assets' growth depend on an individual adult's financial capability.
\end{abstract}

\section{INTRODUCTION}

Commencing in the mid-1990s, financial organizations first began to introduce internet banking. The Finnish Banker's Association reported that approximately $74 \%$ of Finland's private bank customers are presently using internet banking services. During the last few years, digital banking acceptance has increased rapidly. They believe customers have identified the advantages of digital transactions and influenced them to adopt digital banking. As a result, banks have identified the importance of developing, utilizing, and introducing new channels to acquire customer satisfaction. An individual experience has paid attention to the amount of practical learning and investigated the development of digital banking and its operations.

Over the past few years, people have shown more dependence on digital financial transactions than face-to-face business. However, the Oxford English Dictionary defined dependability as "an attribute of consistent quality, performance, or trust." Moreover, information technology and financial knowledge are essential ingredients for a Fintech revolution. Previous research about financial literacy has found that many adults have a poor understanding of finance, influencing their savings and portfolio decisions. Peters, Ameriks, and Lusardi, and Mitchell also provided information about the relationship between digitalization, financial literacy, and an individual adult's saving decisions. 
This project survey applied the idea of both an Instrumental Variable (IV) and Intertemporal Choice Model approach, which has divided the informal effects of financial literacy on wealth accrual. Also, individuals can anticipate their future income and discount interest rates appropriately. Both approaches are variable strategies, and microeconomics data is copied by merging demographical information. This information is a reasonably powerful instrument and explains about $48 \%$ of the variability in financial literacy indicators and $78 \%$ associated with digital knowledge. However, the data has revealed that a higher level of financial capability and digital knowledge is strongly associated with an individual adult's savings. The authors only focus on adult e-financial literacy as the UK government has already added financial capability education in the school's curriculum since September 2014. At the same time, opponents, Xiao, suggested that "financial education in school does not carry enough impact to develop the financial knowledge of an individual." Webley and Nyhus have indicated that "parents' knowledge about financial options and guidance about future financial orientation does impact the savings behavior in adulthood." This research study begins with a literature review of the experiential learning method for e-financial literacy and digitalization advantages with developing hypotheses research methods. Data analysis will place in the second part. The results will be discussed and will provide recommendations to academics in the last section.

A review of the literature from many research studies would indicate that Kolb's (1984) formative effort gives an outline to reassess the process of experiential learning. The experiential learning model of Kolb was reviewed by Sen (1993) and led by Johnson and Sherraden (2007) to improve financial learning capability. They have suggested that a pedagogical method of teaching can build a learner's competencies. Another learning theory suggested in past research is the cross-curriculum. Whitty et al. (1994). Behrman et al. (2012) examined "financial literacy, schooling and wealth accumulation," and in this literature, highlighted how to gain financial literacy by adopting digital knowledge. Therefore, it is essential to implement the pedagogy learning method for online teaching, enabling an individual for distance learning. Simultaneously, the UK government, academic institutions, and financial organizations positively give importance to financial literacy. For example, the London Institute of Banking and Finance (LIBF) has taken several initiatives to support school learners to teach financial capability like Lloyds Money for life, RBS Bank's Money Sense for Schools and Barclays Bank lunch Money Skill, LIBF for "Young Persons' Money Index" and "Financial Skill for life" to develop young people confident in managing their own money. These programs focus on improving learners' life skills knowledge to make efficient household budget and savings decisions. Nevertheless, Financial education is an essential factor in economic well-being.

However, a recent research study has revealed that over the last few years, customers have found increased difficulty when making mortgage and other financial decisions than before as they do not always have the best interest rate calculation in their mind. A USA-based Consumer Financial Protection Agency Fringe Financial Service provider has repeatedly found that "low-income neighborhoods and poor target people are with modest financial literacy." However, recent research has found that learning financial capability from friends and family can restrict an individual from formulating effective financial choices; thus, debt-taken customers cannot relieve themselves shortly. Since the last decade, employers and governments have dedicated their efforts to financial education and retirement planning. However, those efforts have mixed achievements on saving representation, Mitchell and Lusardi (2015). Mitchell and Lusardi (2015) developed a module on financial literacy and planning for the 2004 Retirement and Health Study. However, Financial literacy builds an individual's financial capability to manage money and decide about household finance effectively and efficiently.

Past research has also confirmed that an individual adult's assets growth is dependent on a person's different levels of financial literacy. Mitchell and Lusardi (2015) indicated that unplanned borrowing decisions, lack of financial planning, and market participants could be determined by fundamental financial training. This concept is opposed by Chen and Volpe, who believe that financial decision-making and financial education both experience uncertainty of the financial market. However, another critic Müller and Weber (2010), points out that those investors have the high financial knowledge and usually prefer to invest their money in the reflexive appliance due to low charge rates. On the other hand, Beal and Delpachitra explored that financial literacy and the money market positively support each other. However, according to Chen and Volpe, learning business and economics subjects have increased financial knowledge. 
On the other hand, due to high customer demand, most businesses follow the invisible corporal nature of financial services, which means that business is wholly digitalized with IT. According to Capgemini's World Payment Report (2014), annual online store payment growth is 15\%, and surprisingly, mobile banking transactions' annual growth is 60\%. Dapp (2014) cited that "internet companies innovate online or mobile financial transactions; the idea has not come from traditional financial sectors. According to Brynjolfsson and McAfee (2014) and Pohjola (2014), digital technologies have contributed to worldwide development. Recent competitive analysis by the World Economic Forum (2014) has found that Finland has the best technological resources than any other European country, with Sweden in second.

Therefore, the authors considered e-financial literacy for adult participants as responsible for household financial decision-making. However, the research study was not correlated with school-age participants; therefore, research findings were highly mixed. Most adults do not want to attend generic money management courses because they do not benefit from their lives. At the same time, older adults do not rely on digital transactions. According to Mukherjee and Nath, "the past five years, digital financial transaction acceptance has increased surprisingly. These topics, especially, have taken a high recommendation place in the academic research arena. However, surprisingly this research finding has found that $100 \%$ of participants use smartphones and can operate mobile games and other apps as most of the participants in this research are young adults.

This literature review has confirmed the importance of experiential learning and that digitalization knowledge enables adult learners to develop life skills. Previously, much research about improving financial literacy at the school level was done by the Organisation for Economic Co-operation and Development (OECD) (2013), Robb and Woodyard (2011). Previous research about digitalization was reported by Van Rooiji et al. (2012) and Behrman et al. (2010). However, none of their studies have provided a precise framework and determination to incorporate e-financial literacy about the individual adult's advantages. As a result, they did not find any correlation with any adult's financial literacy test scores. The authors would like to understand a participant's knowledge about digitalization and financial education. Therefore, the hypotheses below have been designed:

\section{Hypothesis Development:}

In this study, the authors used a graphical representation of multiple regression and hypotheses tests to determine the size of the relationship between e-financial literacy and an individual adult's advantages. There are significant differences between gaining financial literacy in school-age and adult age. The report reveals that only $10 \%$ of participants can improve financial literacy knowledge by $\mathrm{R}$ Square value, which is a modest number of improvements.

1. A recent study by Santos et al. (2016), Pires et al. (2013), Potrich et al. (2015), Potrich et al. (2016), based on secondary school students, reported that financial literacy in school correlated negatively with future financial decision making. In this research project, the authors would like to see whether the same result can be achieved by considering adult participants.

There is a positive relationship between digital financial literacy and an adult's assets accumulation.

2. According to Willis (2008), "effective financial literacy education lacks the empirical support." However, this research finding has found that $67 \%$ of adult participants are using digital financial trading with informal financial knowledge. As a result, an individual adult participant could distinguish digital financial transactions with informal financial knowledge that harms formal financial literacy.

So, adults are capable of distinguishing between formal and informal support and the value of digitalization.

3. Over the last few years, research studies about financial literacy and saving have been examined by Jappelli and Padula (2013) and Lusardi (2011) "financial literacy among the young."

However, there is a positive relationship between financial literacy and consumers' saving. 
The above literature review and hypotheses have affirmed that financial education has experienced tremendous changes over the past decade. These days, globalization and digitalization have become key tactical elements. Consequently, it is essential to implement an experiential learning method for e-financial training, enabling an individual adult to make potential financial decisions. The promotion of smartphone digital apps and financial literacy inclusion are mutually exclusive. The following section's research findings will support gathering information for the research-raised questions

\section{METHODS}

This research was based on grounded analysis. The grounded analysis involved comparing and evaluating data findings in the literature review and adopting a qualitative method. Instrumental Variable (IV), Intertemporal Choice Model, and an inductive reasoning mixed approaches support the hypotheses by collecting primary and secondary data, Easterby-Smith et al. (2012). Following the literature review, the survey findings have identified the most appropriate methodology for primary research to support the experimental learning method as previous other authors have provided for financial literacy. Previously, all research sample participants were school learners, but the authors have considered adult participants for findings analysis for this research.

However, in this research study, the authors aim to determine the participants' financial literacy level and digital knowledge about individual adults' advantages. The authors have developed hypotheses, financial literacy tests, survey questionnaires. The survey was carried out by financial professionals and university students in the UK and Bangladesh. Participants' age range was 18 to 75 and above. Twenty-five survey questionnaires were compiled with multiple choice questions, closed questions like yes/no, and Likert model analysis questions were used via the Survey Monkey website (Survey Monkey, 2013). The authors have contacted more than 35 participants via e-mail, phone, Viber, Imo, and messenger, with the interviewer following up the closed questions to meet the research's requirements. The data collected from the questionnaires have been analyzed through MS Excel and SPSS. Survey questionnaires of this research project have been set in two parts for participants. The first part intended to measure demographical factors and self-evaluation factors of participants. The second part measured participant's knowledge about e-financial literacy as well as digitalization apps knowledge. Participants were asked to choose their preference for financial literacy from four choices. $100 \%$ of the participants agreed to use the digital method for their financial transactions. The second part of the questionnaire asked about the value of money and awareness of market and assets accumulation like Mitchell and Lusardi (2015) suggested for financial literacy questions. It was consistent with previous research by Jappelli and Padula (2013).

The questionnaires were set for a financial literacy test. The version of this financial literacy test scale was produced from ePrints. The first financial literacy test involved nine participants. The test papers were handed to participants one week before their second test. One week later, the participants were requested to attend another test. It was consistent with a previous research study by Mitchell and Lusardi (2015).

The authors divided nine participants into three groups for time limitations. Six participants from Bangladesh and three participants from the UK randomly selected them from her previous and present workplace and social media friend list. The authors prefer to meet directly with participants to get a more rational outcome in the research findings. The results are accessible as a percentage of the participants' responses in graphical design or pie charts. The authors considered the whole group of participants for an average result or sometimes split the group for a rational analysis of the participant's financial literacy level. According to Walsh (2013), using two or more research findings is about getting more ideas about human behaviors. The survey research findings are used for multi-purposes to compare it with previous research findings and literature review. However, at the end of the research data analysis, the authors admitted that there are other ways that this should be undertaken this research study. Remarkably, more qualitative approaches involve a set of questionnaires with a wide range of participants from the school level worldwide. It is a growing area for an educational establishment, which has led to the acceptance of a tentative approach. 


\section{RESULTS}

In this research, the authors conducted relevant discussions, focused on prime data findings with graphical analysis, and developed hypotheses based on the financial knowledge test. Data finding statistics analysis is graphically discussed below. The graphical charts will outline the participant's age, gender, occupation, education level, and country of residence.

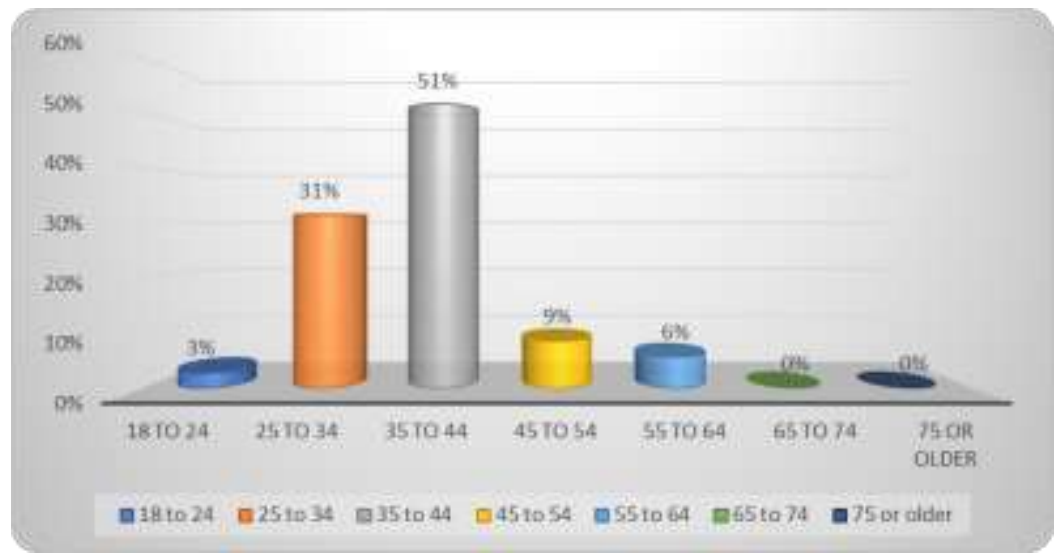

Figure 1. Age of participants (Age \%)

This research study is different from past research findings as it is based on an adult group instead of below age 18. More than half of the participants are between 35 to 44 years old and quickly and willingly provided information. The age group $64+$ participants could not reply to the researcher due to a lack of computer knowledge.

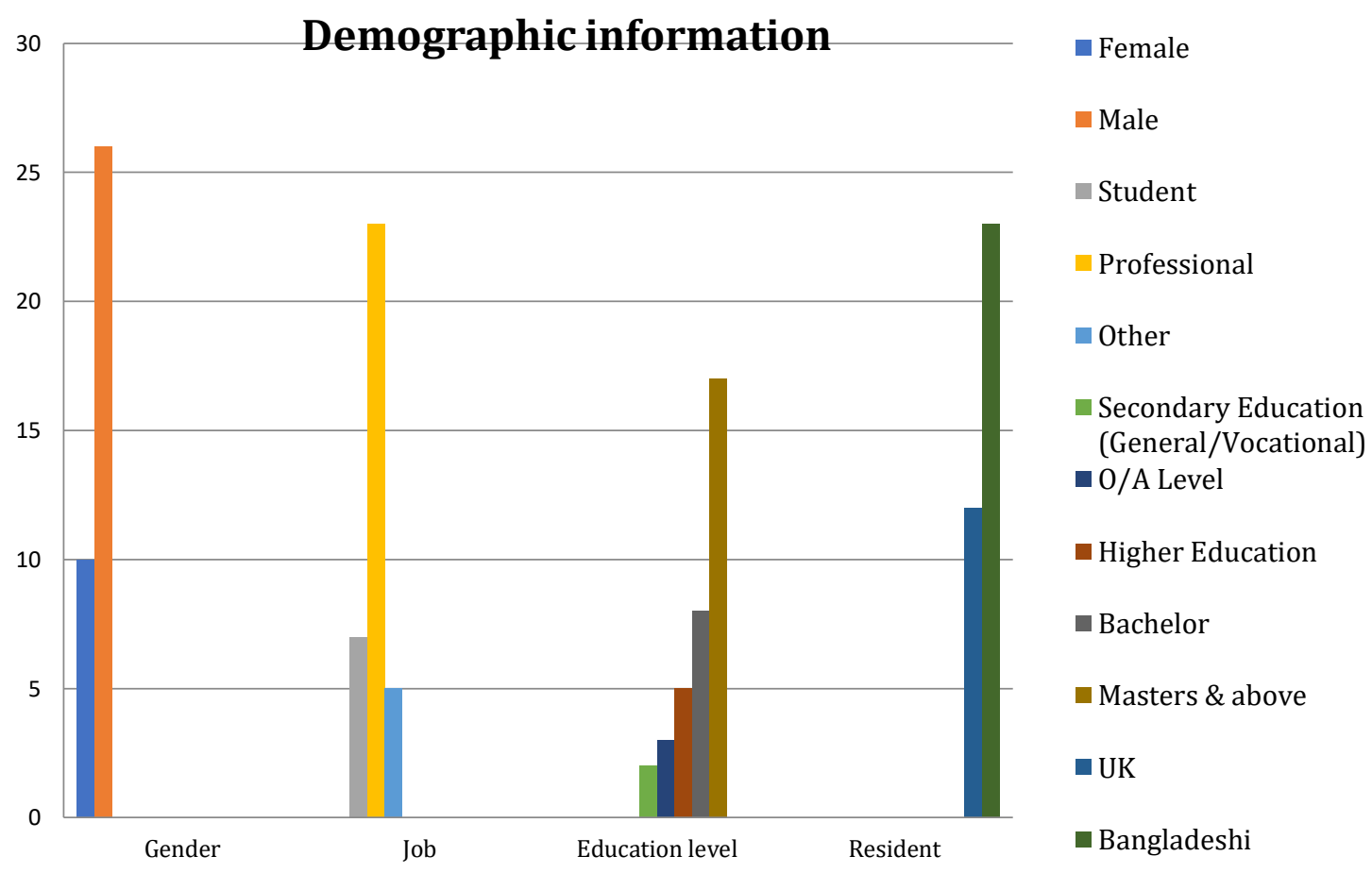

Figure 2. Participants`gender, job, education level, and residence (\%)

The above demographical data clarifies the principal participants. The data found that the majority of the participant's education level is above degree level. The authors have requested 
participants to attend a computer-based financial literacy test to assess their e-financial literacy. The authors develop a hypothesis by setting some survey question naires to understand the participants' financial and ICT knowledge.

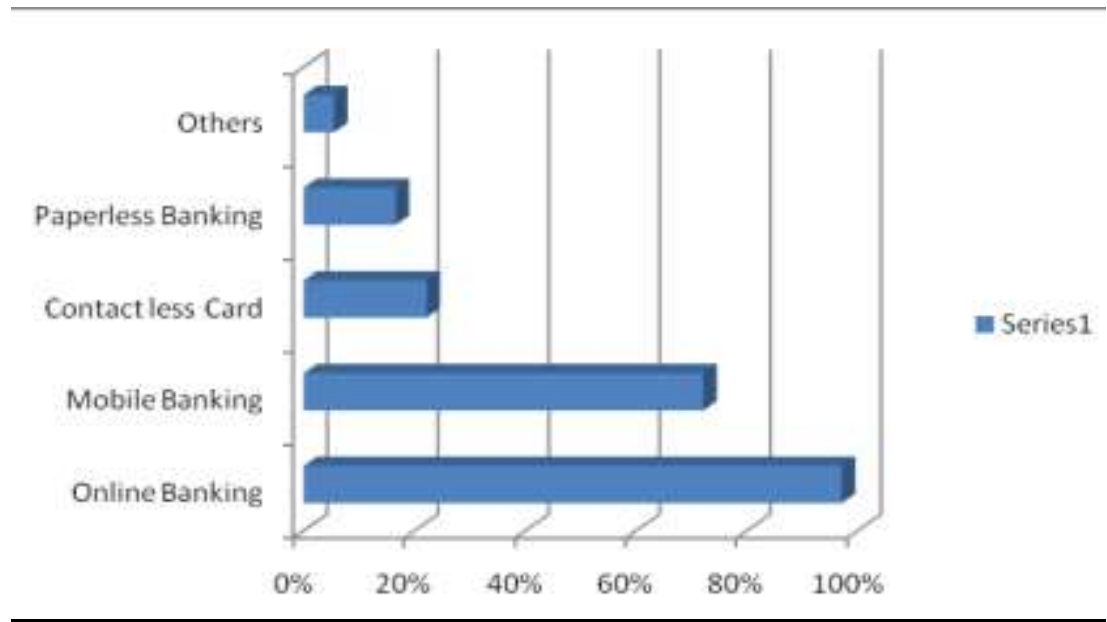

Figure 3. Digital banking usage range (\%)

The above primary data analysis shows that $97 \%$ of participants use online banking, and $78 \%$ use mobile banking. However, the research has found that young adults are more interested in digital financial transactions than older people. The authors have taken a cross-market survey to compare the UK participants' advantages for e-financial literacy with other countries. However, the UK Participants are interested in digital financial transactions free of charge and 24/7 hassle-free usage. However, it is not accessible in Bangladesh. Still, participants are interested in using digital financial transactions for their benefit as they can save time, ensure accuracy of transactions, and are reliable, integrity, and confidentiality of transactions.

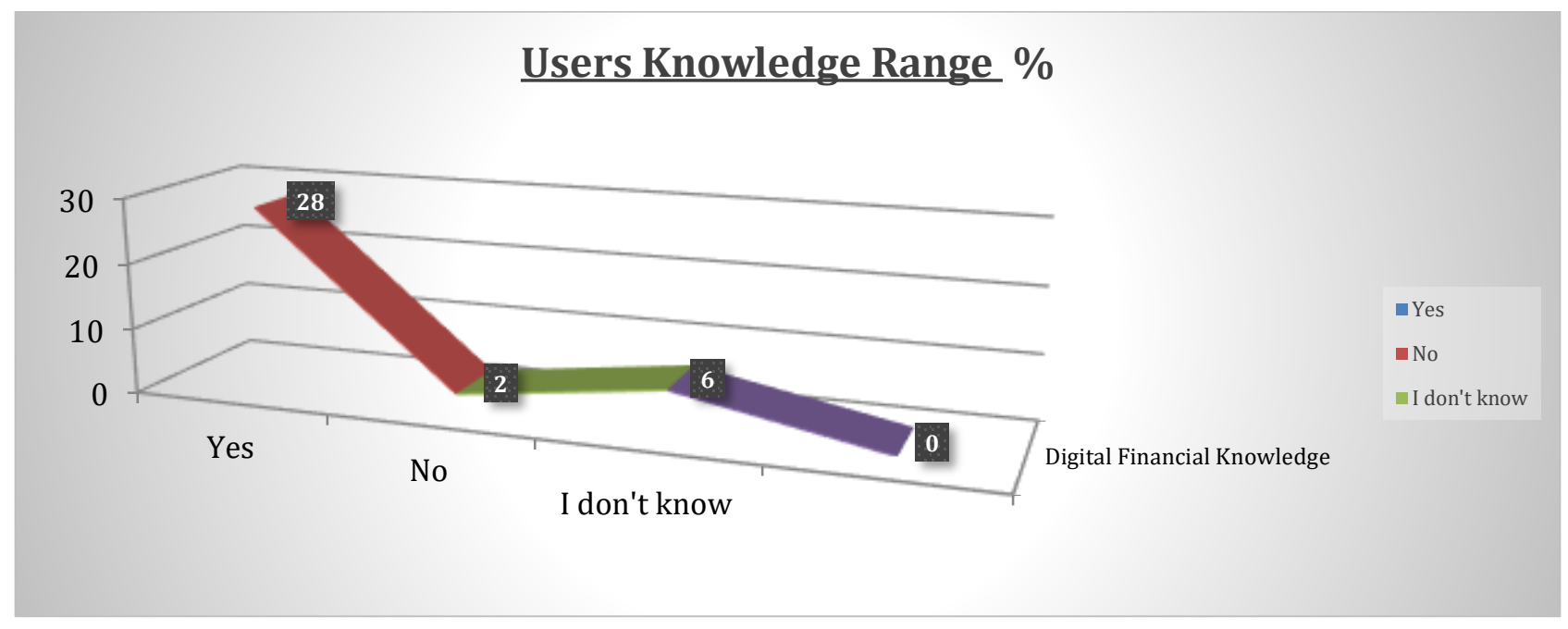

Figure 4. Financial and digitalization knowledge range (\%)

Jappelli and Padula (2013) predicted that "financial literacy and wealth are strongly correlated over the life cycle." Lusardi et al. (2015) suggested a "Multi-period dynamic life cycle model where individuals not only selected capital market for investment but also undertaken investment in financial knowledge." This research's participants are already aware of the advantages of digitalization and financial literacy as they were selected from financial and IT professions. This qualitative research data has shown that e-financial transactions are advantageous for participants. 


\section{Hypothesis 1: There is a positive relationship between financial literacy and digitalization in organizations for individual customer's advantages}

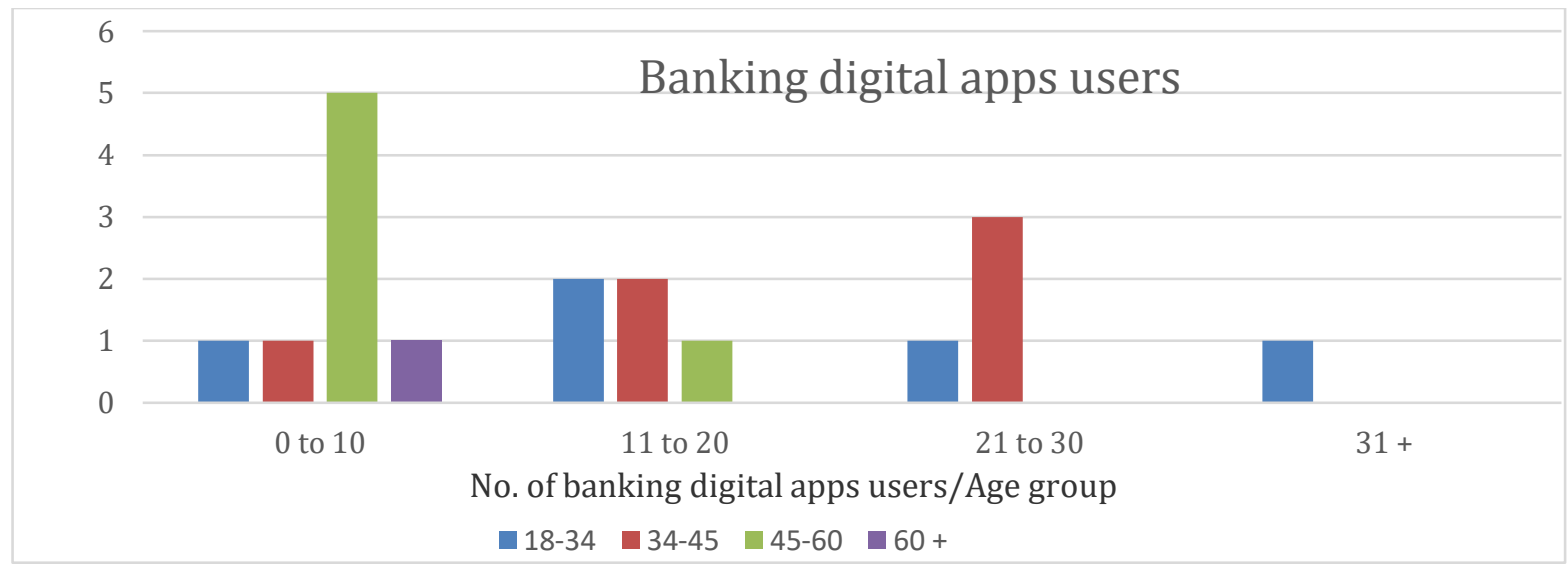

Figure 5. Comparison of banking digital apps users per hour about age:

The data results found that 18 to 45 are primarily involved with digital financial transactions than the age group 60 to $75 \&$ above. The majority of participants are using a smartphone for digital banking. Age groups 45 to 55 are moderate users of mobile banking. The data found that 18 to 34 participants sign into online banking more than ten times per day. On the other hand, the sign-in record of age 60 \& above is $0 \%$ per day. The authors have found that 60 and above do not feel that online banking is secure.

Mean score on both pre and post exposure of financial test

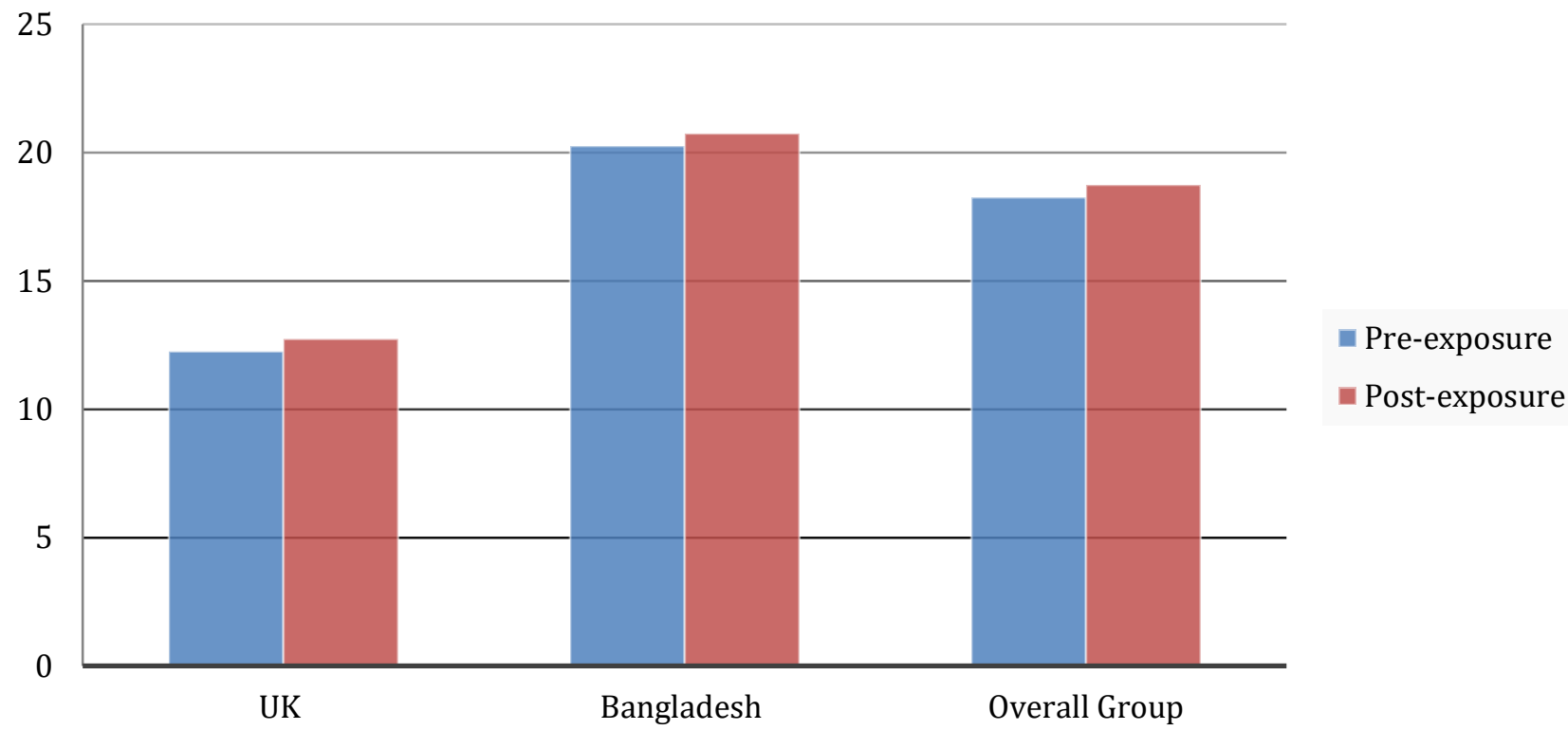

Figure 6. The mean results of pre and post-exposure of financial test

The above research findings have found that $67 \%$ of participants are agreed that financial literacy is helpful for a wealthy life. Financial test results have shown that England's participants' score was significantly lower than Bangladeshi participants. Bangladesh participants' pre-and post-scores are slightly increased; however, that does not reflect a fair representation. The findings have shown that the UK's participants are less interested in learning financial literacy as they are dependent on digital financial transactions. The above findings also found that $78 \%$ of the participants believe that digital 
calculations are accurate and trustworthy. However, some participants were denied using online financial transactions because of their past bad experiences, which influenced second test scores. 82\% of participants' respondents were yes to the question. 100\% of Bangladeshi participants' scores remained the same for online transactions, and even they had a bad online shopping experience. The exposure of financial literacy and digitalization knowledge is a positive effect on e-financial transactions. Forrester's study has shown that USA people prefer online to pay household bills, and the total number of online payments has increased from 48 million to 63 million from 2009 to 2014.

Respondent 16/19 is about their current debts and how much interest they are paying. The majority of the UK participants were not able to answer it correctly. The second test they have taken helps from the online calculation, and still, their understanding is not improved, and therefore the result remained the same. Respondent 18; the majority of participants' responses were using a credit card. When the authors asked them for interest calculation, participants preferred to go for an online report. Only $5 \%$ of participants, who teach financial capability and financial professionals, can solve an accurate calculation. All participants admitted that they might take formal financial education if there were no digital banking systems.

\section{Hypothesis 2: To distinguish between formal and informal financial support and digitalization}

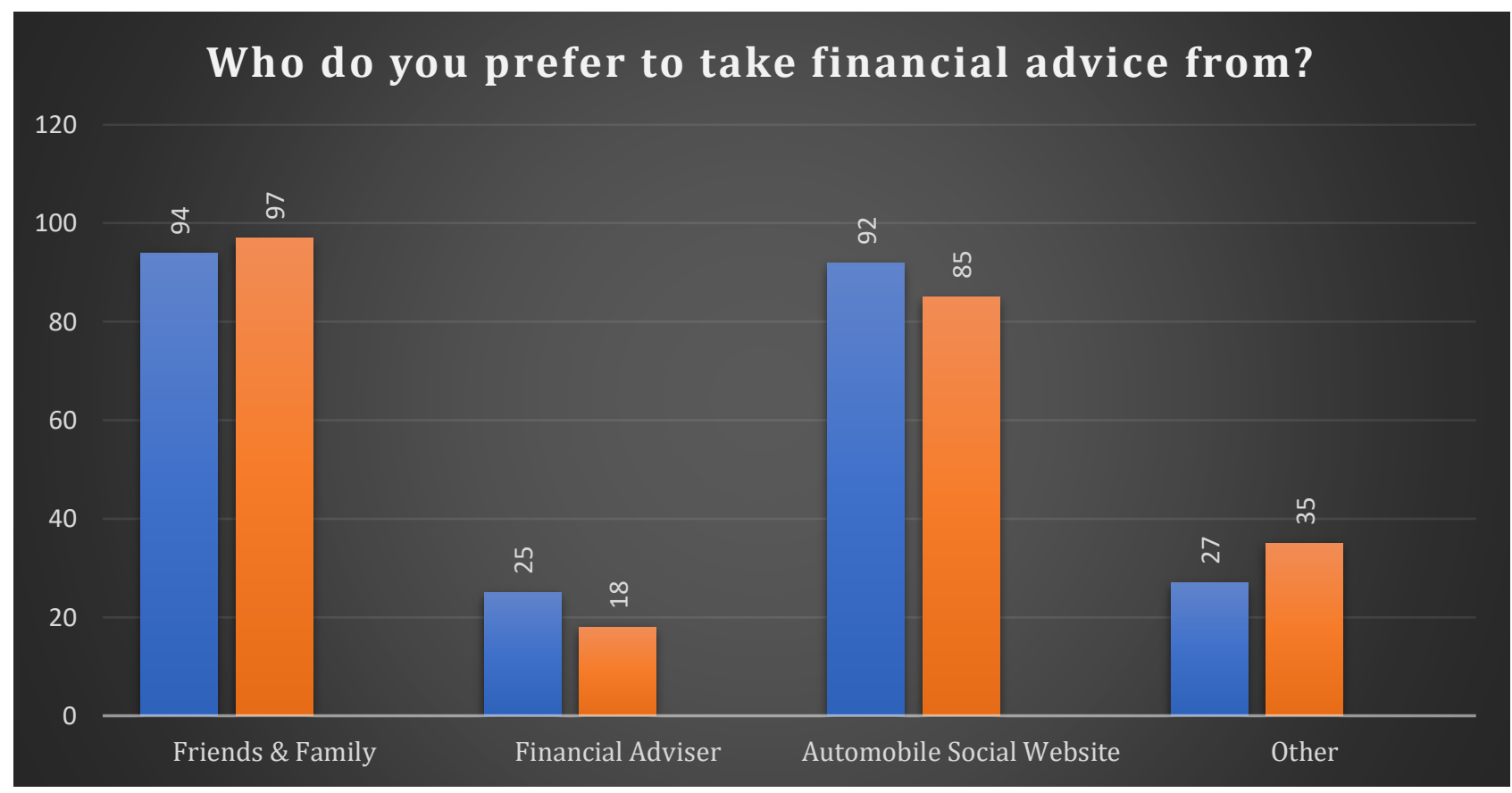

Figure 7. Whom do you prefer to take financial advice from? (\%)

Research findings have shown that those participants usually have taken financial advice from friends and family, the UK group 94\% \& Bangladesh (BD) 97\%, the UK 72\%, and BD. 48\%, from a financial adviser, $25 \%$, and $18 \%$ from automobiles social websites. Others (online, website and general internet search, teachers, and more.) are $27 \%$ \& 35\%. Taking the teacher's and financial adviser support is very low, as participants believe it is costly and time-consuming. The qualitative information gave the reasons for taking financial advice from friends and family as it is easier to understand and accessible. However, Touré (2011) suggested that "taking online support is not only an advantage for users but also affected by digital eccentricity." The qualitative information shows that financial advisers should be treated formally:

1. Respondent: 10, "I considered financial advice should be taken formally from a financial adviser."

2. Respondent: 21: "I like to take formal advice from a financial adviser for my next automobile lease."

3. Respondent 19: "I like to take both formal and informal reports." 
4. Respondent 20: "Because it is an important decision for a family's quality of life, I would like to be formal."

5. Respondent 15: "Online apps have limited information to choose from; therefore, I would like to be formal in this case."

It supports hypothesis 2: The above findings have found that if individual adults have financial literacy, they can distinguish between formal and informal financial services. This statement was challenged by Jappelli and Padula (2013), who reported, "individuals are found in countries with more generous Social Security benefits if they are less financially informed." The research has found that 75\% to $80 \%$ do not take financial adviser support for formal situations.

\section{Hypothesis 3: Exposure of 'digitalization and financial literacy' about customer's savings}

According to Carney (2017), Governor of the Bank of England and Chair of the Financial Stability Board, "Adults who refused to use digital banking are losing an average $£ 744$ a year." (Data collected by Lloyds Bank Consumer Digital Index, 2017). This research finding has found Bangladeshi participants are not saving any service charges for digital financial transactions. Therefore, Bangladesh's digital financial transactions are significantly lower than in England. However, it is not a fair representation as one country charges for digital financial transactions. Another country is entirely free of charge. British Bankers' Association (BBA) Help in Hand's report, 2016, projected that "England average number of visits per day at bank branches will fall from 70 in 2016 to 50 in 2021 for digital banking". Also, according to Forrester (2007, p13), digital banking has grown progressively in the UK over the past decade. At that time, 31\% of the UK online users were young adults. Now, it rose to $60 \%$ in 2016. According to Riemer et al. (2017), "current financial organizations' development areas are noted as mobile banking, digital wallet and buy now pay later as well as Fintech solutions directed to individual users."

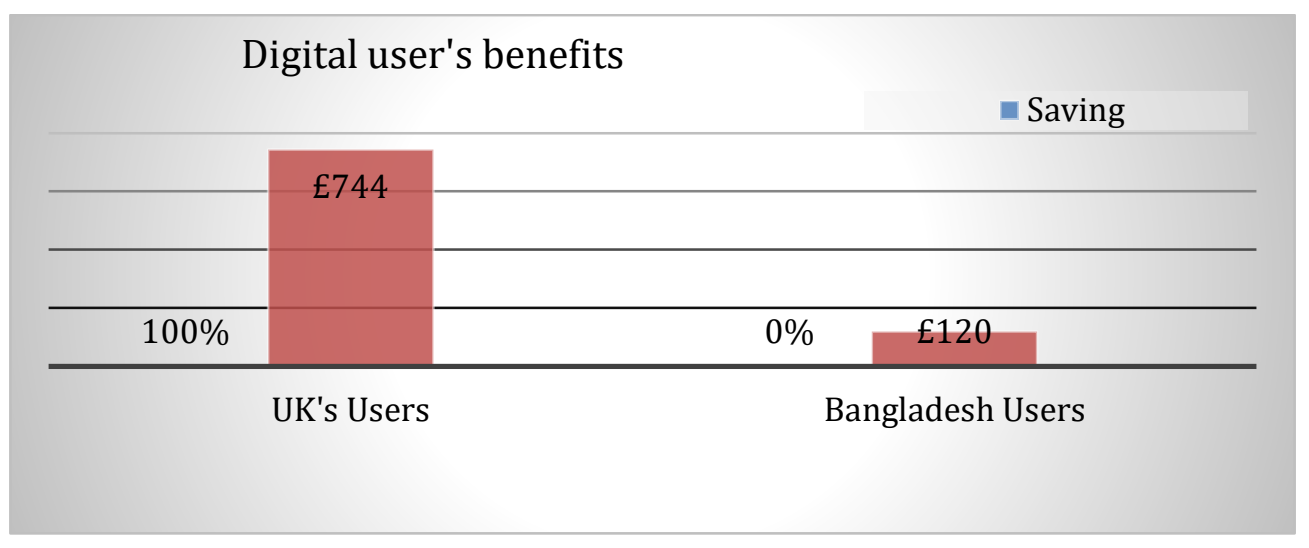

Figure 8. The mean results of the individual customer's advantages:

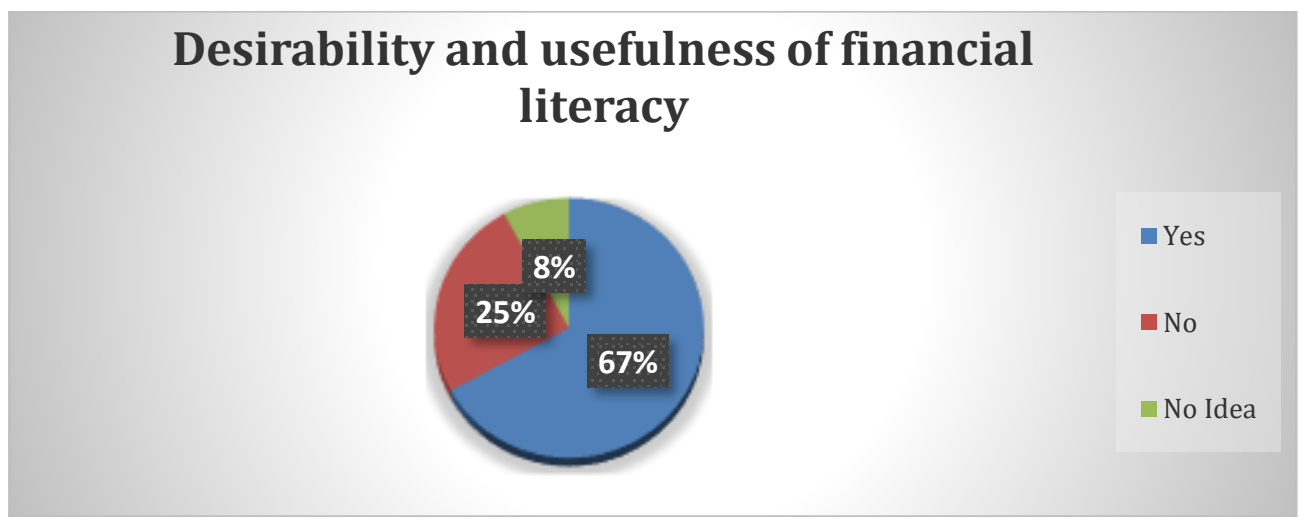

Figure 9. Desirability and usefulness of financial literacy: 
It supports hypothesis 3,_which has shown positive relationships between financial literacy and saving. It has been previously supported by Jappelli and Padula (2013), who found that financial knowledge and saving are positively correlated. As cited by the Hilgert research team, they set 28 passes/fail questions for testing American participants' financial knowledge. Unfortunately, the authors concluded that the majority of participants' scores failed. The National Financial Capability Survey 2009/2012 measuring American people's financial knowledge test also found only $21 \%$ knew about converse relationships between price bond and interest rate., Lusardi (2011). It is determined that most participants (about 66\%) who attended this research study were identified as having a moderate level of financial literacy knowledge. Simultaneously, $82 \%$ of participants were found to have a highly satisfactory knowledge level in digital apps. Xia and Xia (2014) suggested that young adults are positively correlated with digitalization. This research finding also agreed that there is a positive relationship between digitalization and young adult.

According to the research findings, the participants' financial literacy test scores were determined on online value, which is higher than Braunstein and Welch's research findings. This research study aimed to examine and address the main ideas about the value and advantages of financial literacy and digitalization to individual adults. It has been accomplished. The survey suggested valuable information into the participant's advantages of financial literacy and digital financial transactions. However, the summaries of findings were based on adult participants as follows:

1. There is a relationship between financial literacy, digitalization, and individual adult's advantages.

2. Digital knowledge could serve as an opportunity to gain financial capability.

\section{Limitations}

During this research study, the authors had the following main limitations:

1. The research project was designed for a small sample copy; therefore, words and times were limited, which may not signify the school-age population.

2. Because the author's previous statistical experience is limited, applying more complex statistical techniques was limited.

3. The authors determined to accomplish the value and advantages of financial literacy and digitalization for individual adults. Therefore, more examinations could focus on digital financial literacy or the added effect on other literacy skills.

4. This research study is related to the present majority population, and it is a relatively new experience. So, there is limited experiential research to date to compare.

\section{CONCLUSION}

This research project reveals that this research relates favorably with the latest financial literacy research to accumulate wealth and online teaching by Peters, Ameriks and Jappelli, and Padula and Lusardi. They agreed that lack of digitalization knowledge and financial literacy affected adult financial decision-making. $66 \%$ of the participants were affected by financial literacy in this research study. However, this research study is not broad enough to generalize about financial literacy knowledge. However, it should draw attention that after the first exposure of digital financial literacy tests is affected satisfactorily, an individual adult wants to take other financial decisions. This research theme is not straightforward; there are many phases involved, including the durability of mobile transactions and usage of e-financial literacy, create an inclusive learning environment for the distance learning environment, create reliable e-financial literacy apps, distinguishing between formal and informal financial literacy, and the different literacy tests. Furthermore, according to Willis and Potrich, financial literacy at the school level correlates negatively with future financial decision-making; therefore, this research study needs more investigation.

\section{Funding and Conflicts of Interest:}

This article is a part of a student paper of authors in the IFS School of Finance. The authors declare that there is no funding and conflicts of interest for this research. 


\section{REFERENCES}

Behrman, J. R., Mitchell, O. S., Soo, C., \& Bravo, D. (2012). How financial literacy affects household wealth accumulation. American Economic Review, 102(3), p.300-304, EBSCO Business Source Corporate Plus [online]. Available from the KnowledgeBank website at http://search.ebscohost.com/login.aspx?direct=true\&AuthType=url\&db=plh\&AN=75368015 \&site=ehost-live [Accessed: 17 August 2017].

Behrman, Jere, Olivia S. Mitchell, Cindy K. Soo, and David Bravo (2010). "Financial Literacy, Schooling, and Wealth Accumulation." NBER Working Paper 16452, [online]. Available at: http://repository.upenn.edu/cgi/viewcontent.cgi?article=1031\&context=parc working paper s [Accessed: 26 July 2017].

Brynjolfsson, E., MacAfee, A. (2014). The Second Machine Age: w.w. Norton and Company, New York.

Capgeminin, M. L. (2014). World Payment Report 2014, [online]. Available at: https://www.worldpaymentsreport.com/ [Accessed: 26 July 2017].

Carney. M. (2017). The promise of fintech: something new under the sun? Speech at Deutsche Bundesbank G20 conference on "Digitising finance, financial inclusion, and financial literacy," Wiesbaden, 25 January [pdf]. Available at http://www.bankofengland.co.uk/publications/Documents/speeches/2017/speech956.pdf [Accessed: 18 April 2017].

Dapp, T. F. (2014). Fintech- The digital (r) evolution in the financial sector; Algorithm-based banking with the human touch, Deutsche Bank Research, [pdf]. Available at:

https://www.dbresearch.com/PROD/DBR INTERNET ENPROD/PROD0000000000345837/Fintech+\%E2\%80\%93+The+digital+(r)evolution+in +the+f inancia.PDF [Accessed: 28 July 2017].

Easterby-Smith, M., Thorpe, R., and Jackson, P. (2012). Management Research 4th Edition. SAGE.

Forrester, J. W. (2007). UK Online Banking Forecast: 2007 to 2012, p13.

Jappelli, T., \& Padula, M. (2013). Investment in financial literacy and saving decisions. Journal of Banking \& Finance, 37(8), 2779-2792.

Johnson, E., and Sherraden, M. S. (2007). From Financial Literacy to Financial capability among Youth, J. Soc. \& Soc, Welfare, 34, 119, [pdf]. Available at:

https://csd.wustl.edu/publications/Documents/WP06-11.pdf [Accessed: 26 July 2017].

Lusardi, A. (2011). Americans' financial capability (No. w17103). National Bureau of Economic Research.

Mitchell, O. S., \& Lusardi, A. (2015). Financial literacy and economic outcomes: Evidence and policy implications. The journal of retirement, 3(1), 107-114.

Müller, S., Weber, M. (2010). Financial Literacy and Mutual Fund Investments: Who Buys Actively Managed Funds?, Schmalenbach Business Review, Forthcoming.

OECD - Organisation for Economic Co-operation and Development (OECD). (2013). Financial literacy and inclusion: Results of OECD/INFE survey across countries and by gender. Paris, France: OECD Centre.

Pires, D., Lima, O., Dalongaro, R., Silva, P. S., \& Silveira, J. (2013). Educac,ãoFinanceira como Estratégia para Inclusão de Jovens na Bolsa de Valores. Encontros Científicos-Tourism \& Management Studies, 3, 720-730.

Pohjola, M. (2014). Suomi Uuteen Nousuun: ICT ja digitalsaatio tuittavuuden ja talouskasvun lähteinä, Finnish Technology Industries, [pdf]. Available at:

http://teknologiateollisuus.fi/sites/default/files/file attachments/pohjolan raportti suomi u uteen nousuun.pdf [Accessed: 11 July 2017]. 
Potrich, A. C. G., Vieira, K. M., \& Kirch, G. (2015). Determinantes daAlfabetizac ão Financeira: Análise da Influência de Variáveis Socioeconômi-cas e Demográficas. Revista Contabilidade \& Finan, cas, 26(69), 362-377.

Potrich, A. C. G., Vieira, K. M., \& Mendes-Da-Silva, W. (2016). Development of a financial literacy model for university students. The management research review, 39(3), 356-376.Robb, C. A. (2011). Financial knowledge and credit card behavior of college students. Journal of Family and Economic Issues, 32(4), 690-698.

Riemer, K., Hafermalz, E., Roosen, A., Boussand, N., El Aoufi, H., Mo, D., \& Kosheliev, A. (2017). The Fintech Advantage: Harnessing digital technology, keeping the customer in focus. University of Sydney, Business School, and Capgemini, [pdf]. Available at: https://ses.library.usyd.edu.au//bitstream/2123/16259/4/Fintech Report Final Web.pdf [Accessed: 31 July 2017].

Robb, C.A., and Woodyard, A. (2011). Financial Knowledge and Best Practice Behaviours, [pdf]. Available at: http://files.eric.ed.gov/fulltext/EJ941903.pdf [Accessed: 31 July 2017].

Santos, D. B., Mendes-Da-Silva, W., Flores, E., \& Norvilitis, J. M. (2016). Predictors of credit card use and perceived financial well-being in female college students: A Brazil-United States comparative study. International Journal of Consumer Studies, 40(2), 133-142.

Sen, A. (1993). Capability and well-being. In Nussbaum, M and Sen, A (Eds) The Quality of Life. Oxford: Clarendon Press, [pdf]. Available at: http://existencia.org/files/alt-eco/quality.pdf [Accessed: 31 July 2017].

Survey Monkey (2013). Create Surveys, Get Answers, Survey Monkey.com, [Online]. Available at: https://es.surveymonkey.com/ [Accessed: 31 June 2017].

Touré, H. (2011). Statement des Generalsekretärs des UN Institute of Telecommunikaction(ITU) am 26. Januar.

Van Rooij, M. C., Lusardi, A., \& Alessie, R. J. (2012). Financial literacy, retirement planning, and household wealth. The Economic Journal, 122(560), pp449-478, [online]. Available at : http://onlinelibrary.wiley.com/doi/10.1111/j.1468-0297.2012.02501.x/full [Accessed: 26 Luly 2017].

Walsh, K. (2013). When I say triangulation, Medical Education, 47, 9, p. 866, Academic Search Premier, EBSCOhost. [pdf]. Available at: http://search.ebscohost.com/login.aspx?direct=true\&AuthType=url\&db=aph\&AN=89658912 \&site=ehost-live [Accessed: 12 August 2017].

Whitty, G., Rowe, G., \& Aggleton, P. (1994). Subjects and themes in the secondary-school curriculum. Research Papers in Education, 9(2), 159-18.

Willis, L., E. (2008). Against Financial Literacy Education, ExpressO, University of Pennsylvania.

World Economic Forum (2014). The Europe 2020 Competitiveness Report: Building a More Competitive Europe, Geneva [pdf]. Available at: http://www3.weforum.org/docs/CSI/2012/Europe2020 Competitiveness Report 2012.pdf [Accessed: 12 August 2017].

Xia, X., and Xia, Y. (2014). Gold nanocages as multifunctional materials for nanomedicine. Frontiers of Physics, 9(3), 378-384, [online]. Available at: https://link.springer.com/article/10.1007/s11467-013-0318-8 [Accessed: 26 July 2017]. 